\title{
Helichrysum caespititium (DC.) Harv.: Review of its medicinal uses, phytochemistry and biological activities
}

\author{
Alfred Maroyi* \\ Department of Botany, Medicinal Plants and Economic Development (MPED) Research Centre, University of Fort Hare, Alice 5700, South Africa
}

\begin{tabular}{|c|c|}
\hline ARTICLE INFO & ABSTRACT \\
\hline $\begin{array}{l}\text { Received on: } 06 / 04 / 2019 \\
\text { Accepted on: } 18 / 05 / 2019 \\
\text { Available online: } 05 / 06 / 2019\end{array}$ & $\begin{array}{l}\text { Helichrysum caespititium is a valuable and well-known medicinal plant in south and central Africa. The current study } \\
\text { examined ethnomedicinal uses, chemical and biological properties of } H \text {. caespititium. Information on medicinal uses, } \\
\text { phytochemistry, and biological activities of } H \text {. caespititium were assembled from several internet sources which } \\
\text { included Scopus, Google Scholar, Elsevier, Science Direct, Web of Science, Pubmed, SciFinder, and BMC. Additional }\end{array}$ \\
\hline $\begin{array}{l}\text { Key words: } \\
\text { Asteraceae, } \\
\text { ethnopharmacology, } \\
\text { Helichrysum caespititium, } \\
\text { herbal medicine, } \\
\text { southern Africa. }\end{array}$ & $\begin{array}{l}\text { information was sourced from journal articles, scientific reports, theses, books, and book chapters gathered from the } \\
\text { University library. The current study showed that } H \text {. caespititium is used for treating several medical conditions, } \\
\text { particularly respiratory infections, sexually transmitted infections, nausea, headache, wounds, ulceration, and used } \\
\text { as an aphrodisiac. The pharmacological research showed that } H \text {. caespititium extracts and compounds isolated from } \\
\text { the species have antibacterial, antigonorrhea, antimycobacterial, antifungal, antioxidant, and cytotoxicity activities. } \\
\text { This research showed that } H \text {. caespititium is an integral part of indigenous pharmacopeia in southern Africa, but there } \\
\text { is lack of alignment between the ethnomedicinal uses and existing biological screening. Therefore, future research } \\
\text { should focus on evaluation of the chemical and pharmacological properties of } H \text {. caespititium extracts and compounds } \\
\text { isolated from the species. }\end{array}$ \\
\hline
\end{tabular}

\section{INTRODUCTION}

Helichrysum caespititium (DC.) Harv. is a perennial creeping herb (Fig. 1) which belongs to the Asteraceae or Compositae family. The species has been recorded in Lesotho, South Africa, Swaziland, and Zimbabwe (Fabian and Germishuizen, 1997; Germishuizen and Meyer, 2003; Hilliard, 1977; 1983; Hyde et al., 2019). Helichrysum caespititium is known by several vernacular names in southern Africa which include the following: golden everlasting (English), sewejaartjies and speelwonderboom (Afrikaans), phate-ea-naha, boriba, moriri-oa-lefatse, lelulaphooko, and botsiki-nyane (southern Sotho), mabjana, matšana, and mmetse (northern Sotho) (Erasmus et al., 2012; Hutchings and Van Staden, 1994; Pooley, 1998; 2003). A single synonym, "Helichrysum lineare DC. var. caespititium DC.," was found in

"Corresponding Author

Alfred Maroyi, Department of Botany, Medicinal Plants and Economic

Development (MPED) Research Centre, University of Fort Hare,

Alice 5700, South Africa. E-mail: amaroyi@ufh.ac.za the literature (Fabian and Germishuizen, 1997; Germishuizen and Meyer, 2003; Hilliard, 1983; Hyde et al., 2019). The species name caespititium was derived from the Latin word "caespitose" which means very much tufted and matted, in reference to the cushionforming or mat-forming growth habit of the species (Hyde et al., 2019). The height of $H$. caespititium ranges from 10 to $20 \mathrm{~cm}$ has been recorded in open spaces in the grassland and savanna biomes, particularly disturbed areas at an average altitude range of 650 2,440 $\mathrm{m}$ above the sea level (Fabian and Germishuizen, 1997 ; Germishuizen and Meyer, 2003; Hilliard, 1983; Hyde et al., 2019). The leaves are linear, clasping at the base and hairy on both sides (Fig. 1). The leaves are orange gland-dotted with margin rolled under and densely crowded along the stems (Hilliard, 1983; Hyde et al., 2019). The flowers of $H$. caespititium are white to yellow in color and pale furry underneath (Hilliard, 1983; Hyde et al., 2019).

Helichrysum caespititium is a popular herbal medicine throughout its geographical distributional range in Lesotho, South Africa, Swaziland, and Zimbabwe (Arnold et al., 2002; Gelfand et al., 1985; Long, 2005; Moteetee and Van Wyk, 2011). Therefore, $H$. caespititium is regarded as an integral part of traditional pharmacopoeia in southern Africa, with species tolerated and 


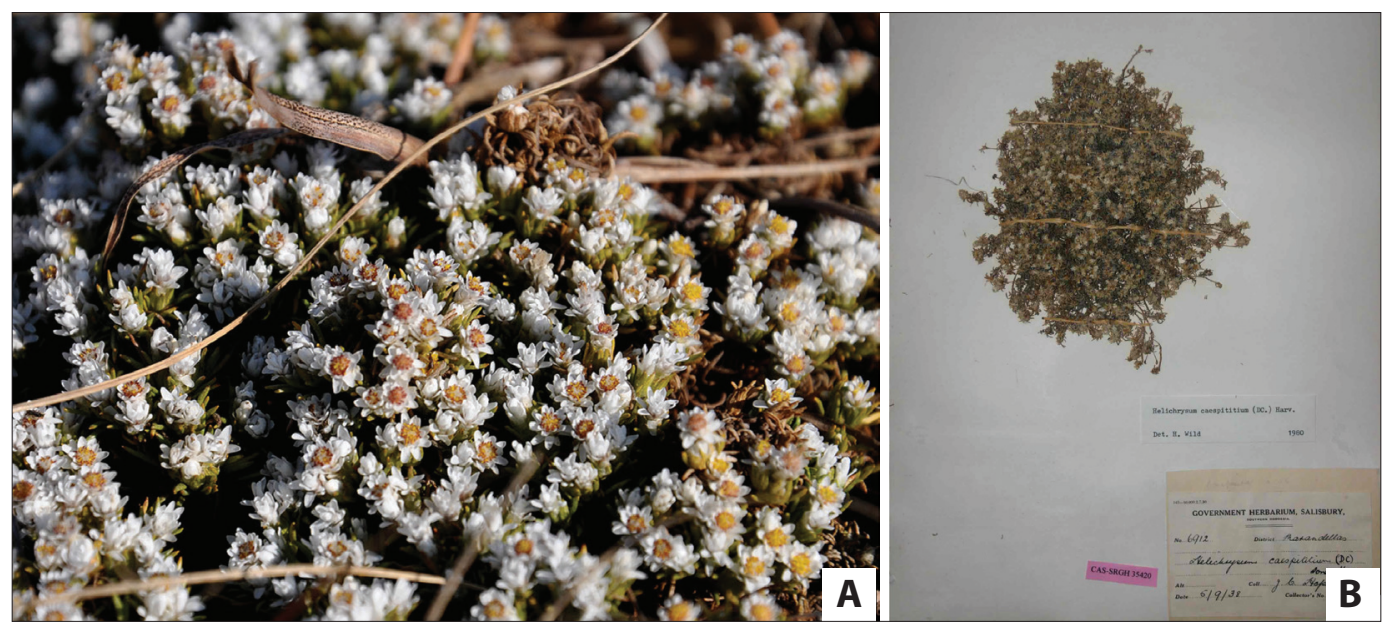

Figure 1. Helichrysum caespititium, (A) a photograph showing an entire plant, the leaves and inflorescence (photo: F Lagarde) and (B) photograph of a herbarium specimen housed in the National Herbarium of Zimbabwe (photo: B Wursten).

managed in domestic home gardens of the North West province of South Africa as herbal medicine (Molebatsi, 2011). Helichrysum caespititium makes an enormous contribution to basic primary healthcare of local people in southern Africa. Therefore, this is the rationale behind the review of ethnopharmacological properties of $H$. caespititium. The current study is aimed at appraising the existing ethnomedicinal value, phytochemistry, and biological activities of the compounds isolated from the species, including $H$. caespititium crude extracts as well as exploring the potential of the species as herbal medicine.

\section{MATERIALS AND METHODS}

Relevant information on medicinal applications, chemistry, phytochemistry, and biological activities of $H$. caespititium were assembled from the several sources which included Scopus, Google Scholar, Elsevier, Science Direct, Web of Science, Pubmed, SciFinder, and BMC. Additional information was sourced from journal articles, scientific reports, theses, books, and book chapters gathered from the University library. The search for this information was carried out between September 2018 and February 2019. The key words used in the search included "ethnobotany," "ethnomedicinal uses," "medicinal uses," "phytochemistry," "biological activities," "pharmacological properties," "toxicological properties," "Helichrysum caespititium," the synonym of the species, "Helichrysum lineare DC. var. caespititium DC." and the English common name "golden everlasting."

\section{RESULTS AND DISCUSSION}

\section{Medicinal uses}

The leaves, roots, and the whole plant of $H$. caespititium are widely used as the herbal medicines for 29 human diseases in south and central Africa (Table 1). Following medical categorization of human diseases and ailments proposed by Cook (1995), Gruca et al. (2014), Macía et al. (2011), and Staub et al. (2015), H. caespititium is mainly used as the herbal medicine against respiratory infections in all the countries where the taxon is indigenous (Fig. 2). Other important medicinal applications include sexually transmitted infections, nausea, aphrodisiac, headache, wounds, and ulceration (Fig. 2). In South Africa, the whole plant of $H$. caespititium is mixed with roots of Callilepis laureola DC. and Osyris lanceolata Hochst. \& Steud., leaves of Lippia javanica (Burm. f.) Spreng., and Tragia dioica Sond. as remedy for fatigue (Semenya and Maroyi, 2018; 2019a). Similarly, the whole plant parts of $H$. caespititium is mixed with bark of Sclerocarya birrea (A.Rich.) Hochst., entire plant parts of Enicostema axillare (Lam.) A. Raynal, and roots of Callilepis laureola as the herbal medicine for pneumonia (Semenya and Maroyi, 2018c; 2019a). In Lesotho, the whole plant of $H$. caespititium is mixed with roots of Dicoma anomala Sond., Scabiosa columbaria L., and Zantedeschia albomaculata (Hook.) Baill. as the herbal medicine for venereal diseases (Maliehe, 1997; Maroyi, 2018; Moteetee and Van Wyk, 2011; Watt and Brandwijk, 1927; Watt and Breyer-Brandwijk, 1962).

\section{Phytochemistry}

Dekker et al. (1983) isolated the phloroglucinol compound, caespitin [2 (4-methylpentanoyl)-4-(3-methylbuten2-yl) phloroglucinol] from whole plant of $H$. caespititium (Fig. 3A). Similarly, Mathekga et al. (2000) isolated a phloroglucinol compound caespitate, often referred to as 2-methyl 4-[2',4',6 trihydroxy-3' (2-methylpropanoyl) phenyl]but-2-enyl acetate from the aerial parts of $H$. caespititium (Fig. 3B). Based on pharmacological evaluations done so far, both caespitin and caespitate have antibacterial and antifungal activities (Dekker et al., 1983; Mathekga, 2001; Mathekga et al., 2000; Van Der Schyf et al., 1986), while caespitate also exhibited antituberculosis activities (Meyer et al., 2002). Documentation of phloroglucinol compounds only highlights an existing gap requiring attention from researchers and future research should focus on the identification and isolation of phytochemical compounds in the utilized parts, particularly aerials parts, stems, and roots.

\section{Biological activities}

The following biological activities have been reported from $H$. caespititium crude extracts and compounds isolated from 
Table 1. Medicinal uses of Helichrysum caespititium.

\begin{tabular}{|c|c|c|c|}
\hline Disease & Parts used & Country & References \\
\hline Anti-emetic & Whole plant & Lesotho & Jacot Guillarmod, 1971; Schmitz, 1982 \\
\hline Aphrodisiac & Roots and whole plant & $\begin{array}{l}\text { Lesotho and South } \\
\text { Africa }\end{array}$ & $\begin{array}{l}\text { Ajao et al., 2018; Jacot Guillarmod, 1971; Lourens et al., 2008; Maliehe, 1997; Moffett, } \\
\text { 2010; Moteetee } \text { et al., 2018; Moteetee and Seleteng-Kose, 2016; Schmitz, 1982; } \\
\text { Seleteng-Kose } \text { et al., 2015; Watt and Breyer-Brandwijk, } 1962\end{array}$ \\
\hline Boost immunity & Whole plant & Lesotho & Mugomeri et al., 2016a \\
\hline Burnt as incense & Whole plant & Lesotho & Moteetee et al., 2018 \\
\hline Depressed fontanelle & Whole plant & Zimbabwe & Gelfand et al., 1985 \\
\hline Diabetes mellitus & Whole plant & South Africa & Adebayo and Masoko, 2017; Chinsembu, 2018; Semenya et al., 2012 \\
\hline Fatigue & $\begin{array}{l}\text { Whole plant mixed with roots of } \\
\text { Callilepis laureola DC. and Osyris } \\
\text { lanceolata Hochst. \& Steud., leaves } \\
\text { of Lippia javanica (Burm. f.) Spreng. } \\
\text { and Tragia dioica Sond. }\end{array}$ & South Africa & Semenya and Maroyi, 2018; 2019a \\
\hline Fumigant & Whole plant & Lesotho & Moteetee et al., 2018 \\
\hline $\begin{array}{l}\text { Gastro-intestinal tract } \\
\text { problems and diarrhea }\end{array}$ & Whole plant & South Africa & Mamabolo et al., 2018; Semenya and Maroyi, 2012 \\
\hline Headache & Whole plant & $\begin{array}{l}\text { South Africa and } \\
\text { Zimbabwe }\end{array}$ & $\begin{array}{l}\text { Hutchings and Van Staden, 1994; Hutchings et al., 1996; Meyer et al., 2002; Reddy, } \\
\text { 2007; Watt and Breyer-Brandwijk, } 1962\end{array}$ \\
\hline Hypertension & Whole plant & South Africa & Semenya and Wadesango, 2018 \\
\hline Intestinal worms & Whole plant & Lesotho & Seleteng-Kose et al., 2015; Watt and Breyer-Brandwijk, 1962 \\
\hline Liver problems & Whole plant & Lesotho & Seleteng-Kose et al., 2015 \\
\hline Nausea & Whole plant & $\begin{array}{l}\text { Lesotho, South } \\
\text { Africa and } \\
\text { Swaziland }\end{array}$ & $\begin{array}{l}\text { Long, 2005; Lourens et al., 2008; Seleteng-Kose et al., 2015; Watt and Breyer- } \\
\text { Brandwijk, } 1962\end{array}$ \\
\hline $\begin{array}{l}\text { Respiratory infections (chest } \\
\text { pains, colds, cough, flu, } \\
\text { pneumonia, sinuses and } \\
\text { tuberculosis) }\end{array}$ & Leaves, roots and whole plant & $\begin{array}{l}\text { Lesotho, South } \\
\text { Africa, Swaziland } \\
\text { and Zimbabwe }\end{array}$ & $\begin{array}{l}\text { Dekker et al., 1983; Jacot Guillarmod, 1971; Gelfand et al., 1985; Hutchings and Van } \\
\text { Staden, 1994; Hutchings et al., 1996; Maliehe, 1997; Mamabolo et al., 2017; 2018; } \\
\text { Mammino and Kabanda, 2007; 2012; Mathekga, 2001; Mathekga et al., 2000; Meyer } \\
\text { et al., 2002; Mugomeri et al., 2016a; 2016b; Long, 2005; Reddy, 2007; Moteetee and } \\
\text { Van Wyk, 2011; Schmitz, 1982; Seleteng-Kose et al., 2015; Semenya and Maroyi, } \\
\text { 2018b; 2019b; Watt and Breyer-Brandwijk, } 1962\end{array}$ \\
\hline Pneumonia & $\begin{array}{l}\text { Whole plant mixed with bark } \\
\text { of Sclerocarya birrea (A.Rich.) } \\
\text { Hochst., entire plant of Enicostema } \\
\text { axillare (Lam.) A. Raynal and root of } \\
\text { Callilepis laureola }\end{array}$ & South Africa & Semenya and Maroyi, 2018c; 2019a \\
\hline $\begin{array}{l}\text { Sexually transmitted diseases } \\
\text { and gonorrhoea }\end{array}$ & Whole plant & $\begin{array}{l}\text { Lesotho, South } \\
\text { Africa and } \\
\text { Zimbabwe }\end{array}$ & $\begin{array}{l}\text { Erasmus et al., 2012; Gelfand et al., 1985; Mathekga, 2001; Mamabolo et al., 2017; } \\
\text { Mammino and Kabanda, 2007,2012; Seleteng-Kose } \text { et al., 2015; Seleteng-Kose et al., } \\
\text { 2019; Semenya et al., 2013; Watt and Breyer-Brandwijk, } 1962\end{array}$ \\
\hline Venereal diseases & $\begin{array}{l}\text { Whole plant mixed with roots of } \\
\text { Dicoma anomala Sond., Scabiosa } \\
\text { columbaria } \text { L. and Zantedeschia } \\
\text { albomaculata (Hook.) Baill. }\end{array}$ & Lesotho & $\begin{array}{l}\text { Maliehe, 1997; Maroyi, 2018; Moteetee and Van Wyk, 2011; Watt and Brandwijk, 1927; } \\
\text { Watt and Breyer-Brandwijk, } 1962\end{array}$ \\
\hline Skin infections & Whole plant & South Africa & Mamabolo et al., 2018 \\
\hline Ulceration & Whole plant & $\begin{array}{l}\text { South Africa and } \\
\text { Zimbabwe }\end{array}$ & $\begin{array}{l}\text { Gelfand et al., 1985; Mammino and Kabanda, 2007; Mathekga, 2001; Watt and } \\
\text { Breyer-Brandwijk, } 1962\end{array}$ \\
\hline Wounds & Whole plant & $\begin{array}{l}\text { Lesotho and South } \\
\text { Africa }\end{array}$ & $\begin{array}{l}\text { Mamabolo et al., 2017; Mammino and Kabanda, 2012; Mathekga, 2001; Watt and } \\
\text { Breyer-Brandwijk, } 1962\end{array}$ \\
\hline
\end{tabular}

the species (Table 2): antibacterial (Dekker et al., 1983; Mamabolo et al., 2017; Mathekga, 2001; Mathekga et al., 2000; SeletengKose et al., 2019; Van der Schyf et al., 1986), antigonorrhea (Mamabolo et al., 2018), antimycobacterial (Meyer et al., 2002), antifungal (Dekker et al., 1983; Mathekga, 2001; Mathekga et al., 2000; Seleteng-Kose et al., 2019; Van der Schyf et al., 1986), antioxidant (Mamabolo et al., 2017), and cytotoxicity (Mamabolo et al., 2018) activities.

\section{Antibacterial activities}

Preliminary evaluation of antibacterial activities of the compound caespitin isolated from $H$. caespititium by Dekker et al.
(1983) showed that the compound exhibited significant antibacterial activities against Streptococcus pyogenes and Staphylococcus aureus; however, the screening method used or the activity level are not indicated in the paper. Similarly, Van der Schyf (1986) assessed antibacterial properties of caespitin identified from $H$. caespititium against $S$. pyogenes, Proteus mirabilis, Pseudomonas aeruginosa, Escherichia coli, and $S$. aureus using a serial dilution method. The compound exhibited activities against $S$. pyogenes and $S$. aureus with the minimum inhibitory concentration (MIC) value of $8.0 \mu \mathrm{g} / \mathrm{ml}$ and the minimum bactericidal concentration (MBC) value of $16.0 \mu \mathrm{g} / \mathrm{ml}$ (Van der Schyf, 1986). Mathekga (2001) and Mathekga et al. (2000) evaluated the antibacterial 


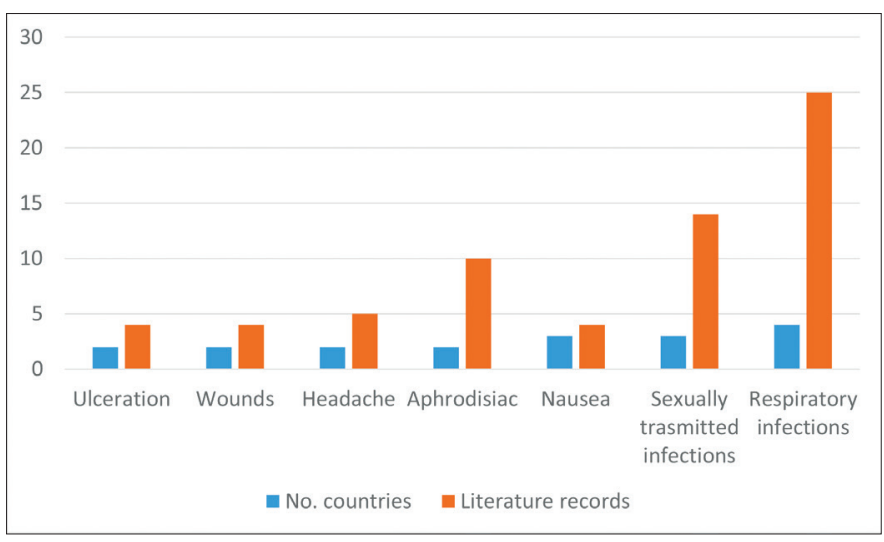

Figure 2. Diseases and ailments treated by Helichrysum caespititium in southern Africa.

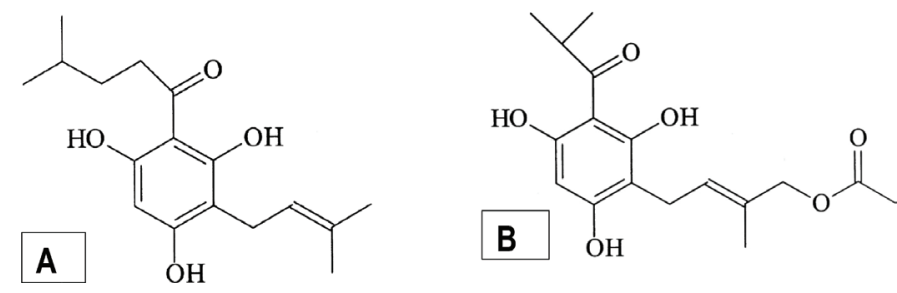

Figure 3. Chemical structures of phloroglucinol compounds, caespitin (A) and caespitate (B) isolated from Helichrysum caespititium.

activities of acetone extracts of aerial parts of $H$. caespititium against Bacillus subtilis, Enterobacter cloacae, Bacillus cereus, P. aeruginosa, Bacillus pumilus, Micrococcus kristinae, S. aureus, E. coli, Serratia marcescens, and Klebsiella pneumoniae using the agar dilution technique. The extract exhibited activities against all the tested pathogens, except $S$. marcescens and $K$. pneumoniae with MIC value of $1.0 \mathrm{mg} / \mathrm{ml}$ (Mathekga, 2001; Mathekga et al., 2000). Mathekga et al. (2000) assessed the antibacterial properties of the compounds caespitin and caespitate against $E$. cloacae, $B$. pumilus, M. kristinae, E. coli, B. subtilis, S. aureus, S. marcescens, $K$. pneumoniae, B. cereus, and $P$. aeruginosa using agar dilution method. Both compounds, caespitin and caespitate were active against B. subtilis, M. kristinae, B. pumilus, S. aureus, and $B$. cereus with the MIC value range of 0.5 to $1.0 \mu \mathrm{g} / \mathrm{ml}$ (Mathekga, et al. 2000). Mathekga (2001) also evaluated the synergistic antibacterial activities of the compounds caespitate and caespitin isolated from $H$. caespititium against $B$. subtilis, $K$. pneumoniae, M. kristinae, E. cloacae, B. pumilus, S. marcescens, S. aureus, B. cereus, E. coli, and $P$. aeruginosa using agar dilution method. Caespitate and caespitin exhibited antibacterial activities against S. aureus, B. cereus, M. kristinae, B. subtilis, and B. pumilus with MIC values ranging from 0.5 to $1.0 \mu \mathrm{g} / \mathrm{ml}$. The combination of caespitin and caespitate maintained their original antibacterial activities against all the tested pathogens except $S$. marcescens and also enhanced their synergistic effects with MIC values within the range of $0.05-0.1 \mu \mathrm{g} / \mathrm{ml}$ (Mathekga, 2001). Mamabolo et al. (2017) assessed antibacterial properties of $n$-hexane, dichloromethane, acetone, methanol and aqueous extracts of whole plant of $H$. caespititium against Klebsiella oxytoca, B. cereus, Enterococcus faecalis, B. subtilis, E. cloacae, Mycobaterium smegmatis, E. coli,
K. pneumoniae, Proteus vulgaris, Staphylococcus epidermidis, $P$. aeruginosa, P. mirabilis, $S$. aureus, and Enterobacter aerogenes using the microdilution technique with streptomycin and nalidixic acid as positive drugs. The extracts showed antibacterial activities against all the tested pathogens with the MIC values within the range of $0.01-0.4 \mathrm{mg} / \mathrm{ml}$ (Mamabolo et al., 2017). Seleteng-Kose et al. (2019) assessed the properties of organic and water extracts of whole plant parts of $H$. caespititium against Neisseria gonorrhoeae, Gardnerella vaginalis, and Oligella ureolytica using the microdilution technique with ciprofloxacin $(0.01 \mathrm{mg} / \mathrm{ml})$ as the positive drug. The organic extracts showed moderate properties against $G$. vaginalis and $N$. gonorrhoeae with the MIC value of 0.1 and 0.06 $\mathrm{mg} / \mathrm{ml}$. The MIC value of organic extract against $O$. ureolytica was $7.2 \mathrm{mg} / \mathrm{ml}$, while aqueous extract showed the MIC values of $>8.0$ $\mathrm{mg} / \mathrm{ml}$ against all the tested pathogens (Seleteng-Kose et al., 2019).

\section{Antigonorrhea activities}

Mamabolo et al. (2018) assessed the antigonorrhea properties of n-hexane, dichloromethane, methanol and aqueous extracts of whole plant of $H$. caespititium against strains $\mathrm{F}, \mathrm{N}$, $\mathrm{O}$, and $\mathrm{G}$ of $N$. gonorrhoeae using micro-dilution technique with gentamicin and amoxicillin as positive drugs. The extracts showed properties with the MIC values within the range of 0.04 to $>0.3$ $\mathrm{mg} / \mathrm{ml}$ which were within the same range of MIC values of $0.2-$ $0.3 \mathrm{mg} / \mathrm{ml}$ exhibited by the controls (Mamabolo et al., 2018).

\section{Antimycobacterial activities}

Meyer et al. (2002) evaluated the antimycobacterial properties of acetone and aqueous leaf extract of $H$. caespititium against a drug-sensitive strain of Mycobacterium tuberculosis using the agar plate technique. Meyer et al. (2002) also evaluated the antimycobacterial activities of the phloroglucinol compound, caespitate isolated from $H$. caespititium against drug-resistant and drug sensitive strains of $M$. tuberculosis. The acetone extract showed activities against the tested pathogens at a concentration of $0.5 \mathrm{mg} / \mathrm{ml}$ whereas, M. tuberculosis was susceptible to the aqueous extract at $5.0 \mathrm{mg} / \mathrm{ml}$. The activities exhibited by the acetone extract against $M$. tuberculosis were corroborated by the use of the rapid radiometric method and the MIC value was found to be $0.1 \mathrm{mg} / \mathrm{ml}$. The MIC value of caespitate was determined to be $0.1 \mathrm{mg} / \mathrm{ml}$ for the M. tuberculosis strains (Meyer et al., 2002).

\section{Antifungal activities}

Preliminary evaluation of antifungal activities of the compound caespitin isolated from H. caespititium by Dekker et al. (1983) showed that the compound exhibited significant antifungal activities against Trichophyton mentagrophytes, Trichophyton rubrum, Microsporum canis, and Cryptococcus neoformans; however, the screening method used or the activity level are not indicated in the paper. Van der Schyf et al. (1986) evaluated antifungal activities of the compound caespitin isolated from $H$. caespititium against Candida albicans, Candida tropicalis, Absidia corymbifera, Aspergillus fumigatus, Sporotrichum schenkii, T. rubrum, M. canis, and T. mentagrophytes using a serial dilution technique and nystatin as the positive drug. The compound exhibited best activities against $T$. rubrum, $M$. canis, and T. mentagrophytes with MIC and the minimum fungicidal concentration (MFC) values within the range of $6.0-13.0 \mu \mathrm{g} / \mathrm{ml}$, while MIC and MFC 
Table 2. Summary of biological activities of Helichrysum caespititium crude extracts and compounds isolated from the species.

\begin{tabular}{|c|c|c|c|c|c|}
\hline Activity tested & Extract & $\begin{array}{l}\text { Plant part/ } \\
\text { compound }\end{array}$ & Model & Effect & Reference \\
\hline Antibacterial & Not applicable & Caespitin & Not mentioned & $\begin{array}{l}\text { Exhibited significant antibacterial activities against } S \text {. aureus and } S \text {. } \\
\text { pyogenes (level of activity not indicated) }\end{array}$ & Dekker et al., 1983 \\
\hline Antibacterial & Not applicable & Caespitin & Serial dilution method & $\begin{array}{l}\text { Exhibited activities against } S \text {. pyogenes and } S \text {. aureus with } \\
\text { minimum inhibitory concentration (MIC) and minimum } \\
\text { bactericidal concentration (MBC) values of } 8.0 \text { and } 16.0 \mu \mathrm{g} / \mathrm{ml} \text {, } \\
\text { respectively }\end{array}$ & Van der Schyf et al., 1986 \\
\hline Antibacterial & Acetone & Aerial parts & Agar dilution method & $\begin{array}{l}\text { Exhibited activities against } P \text {. aeruginosa, B. cereus, } M \text {. kristinae, } \\
\text { B. pumilus, E. cloacae, B. subtilis, E. coli, and S. aureus with MIC } \\
\text { value of } 1.0 \mathrm{mg} / \mathrm{ml}\end{array}$ & Mathekga et al., 2000 \\
\hline Antibacterial & Acetone & Aerial parts & Agar dilution method & $\begin{array}{l}\text { Exhibited activities against } S \text {. aureus, B. cereus, E. coli, B. subtilis, } \\
\text { M. kristinae, B. pumilus, E. cloacae, and } P \text {. aeruginosa with MIC } \\
\text { value of } 1.0 \mathrm{mg} / \mathrm{ml}\end{array}$ & Mathekga, 2001 \\
\hline Antibacterial & Not applicable & Caespitin & Agar dilution method & $\begin{array}{l}\text { Exhibited activities against } S \text {. aureus, B. cereus, B. subtilis, B. } \\
\text { pumilus, and } M \text {. kristinae with MIC value of } 1.0 \mu \mathrm{g} / \mathrm{ml}\end{array}$ & Mathekga et al., 2000 \\
\hline Antibacterial & Not applicable & Caespitate & Agar dilution method & $\begin{array}{l}\text { Exhibited activities against } M \text {. kristinae, B. cereus, B. subtilis, } S \text {. } \\
\text { aureus, and B. pumilus with MIC value of } 0.5 \mu \mathrm{g} / \mathrm{ml}\end{array}$ & Mathekga et al., 2000 \\
\hline Antibacterial & Not applicable & $\begin{array}{l}\text { Caespitate and } \\
\text { caespitin }\end{array}$ & Agar dilution method & $\begin{array}{l}\text { Exhibited activities with } \mathrm{MIC} \text { value of } 0.05 \mu \mathrm{g} / \mathrm{ml} \text { against } K \text {. } \\
\text { pneumoniae, B. cereus, B. subtilis, } S \text {. aureus, } M . \text { kristinae, and } B \text {. } \\
\text { pumilus, and MIC value of } 0.01 \mu \mathrm{g} / \mathrm{ml} \text { against } E \text {. cloacae and } E \text {. } \\
\text { coli }\end{array}$ & Mathekga, 2001 \\
\hline Antibacterial & Acetone & Whole plant & Microdilution method & $\begin{array}{l}\text { Exhibited activities with MIC values of } 0.01 \mathrm{mg} / \mathrm{ml} \text { against } P \text {. } \\
\text { vulgaris; } S . \text { epidermidis }(0.02 \mathrm{mg} / \mathrm{ml}) ; E \text {. coli, E. aerogenes, } B . \\
\text { subtilis, } E \text {. faecalis, and } E . \text { cloacae, and }(0.2 \mathrm{mg} / \mathrm{ml}) ; \text { B. cereus, } K \text {. } \\
\text { oxytoca, K. pneumoniae, } \text {. smegmatis, } P . \text { vulgaris, P. aeruginosa, } \\
\text { P. mirabilis, and } S \text {. aureus }(0.4 \mathrm{mg} / \mathrm{ml})\end{array}$ & Mamabolo et al., 2017 \\
\hline Antibacterial & Aqueous & Whole plant & Microdilution method & $\begin{array}{l}\text { Exhibited activities with } \mathrm{MIC} \text { values of } 0.01 \mathrm{mg} / \mathrm{ml} \text { against } K \text {. } \\
\text { oxytoca and } S \text {. epidermidis; E. faecalis, and } P \text {. vulgaris }(0.02 \\
\mathrm{mg} / \mathrm{ml}) ; \text { K. pneumoniae, B. cereus, E. aerogenes, E. coli, } M \text {. } \\
\text { smegmatis, P. aeruginosa, E. cloacae, P. mirabilis, S. aureus, and } \\
\text { B. subtilis, }(0.4 \mathrm{mg} / \mathrm{ml})\end{array}$ & Mamabolo et al., 2017 \\
\hline Antibacterial & Dichloromethane & Whole plant & Microdilution method & $\begin{array}{l}\text { Exhibited activities with } \mathrm{MIC} \text { values of } 0.01 \mathrm{mg} / \mathrm{ml} \text { against } E \text {. } \\
\text { faecalis, E. coli, and } P \text {. vulgaris; } K \text {. pneumoniae }(0.02 \mathrm{mg} / \mathrm{ml}) \text {; } \\
\text { B. cereus, E. aerogenes, B. subtilis, E. cloacae, } \text {. oxytoca, } P \text {. } \\
\text { mirabilis, S. aureus, } P . \text { aeruginosa, and } S . \text { epidermidis }(0.2 \mathrm{mg} / \mathrm{ml}) \text {, } \\
\text { and } M . \text { smegmatis }(0.4 \mathrm{mg} / \mathrm{ml})\end{array}$ & Mamabolo et al., 2017 \\
\hline Antibacterial & n-hexane & Whole plant & Microdilution method & $\begin{array}{l}\text { Exhibited activities with MIC values of } 0.01 \mathrm{mg} / \mathrm{ml} \text { against } S \text {. } \\
\text { epidermidis; E. faecalis, and } P \text {. vulgaris }(0.02 \mathrm{mg} / \mathrm{ml}) ; B . \text { subtilis, } \\
\text { K. oxytoca, K. pneumoniae, } M . \text { smegmatis, and } S . \text { aureus }(0.1 \mathrm{mg} / \\
\mathrm{ml}) ; \text { B. cereus, E. aerogenes, E. coli, } P \text {. mirabilis and } P \text {. aeruginosa } \\
(0.2 \mathrm{mg} / \mathrm{ml}), \text { and } \text { E. cloacae }(0.4 \mathrm{mg} / \mathrm{ml}) \text {. }\end{array}$ & Mamabolo et al., 2017 \\
\hline Antibacterial & Methanol & Whole plant & Microdilution method & $\begin{array}{l}\text { Exhibited activities with MIC value of } 0.02 \mathrm{mg} / \mathrm{ml} \text { against } E \text {. coli, } \\
K \text {. pneumoniae, and } P . \text { vulgaris }(0.05 \mathrm{mg} / \mathrm{ml}) ; S \text {. aureus, and } S . \\
\text { epidermidis }(0.1 \mathrm{mg} / \mathrm{ml}) ; \text { B. cereus, B. subtilis, E. aerogenes, } E \text {. } \\
\text { cloacae, E. faecalis, K. oxytoca, M. smegmatis, } P \text {. mirabilis, and } P \text {. } \\
\text { aeruginosa }(0.2 \mathrm{mg} / \mathrm{ml})\end{array}$ & Mamabolo et al., 2017 \\
\hline Antibacterial & Aqueous & Whole plant & Micro-dilution assay & $\begin{array}{l}\text { Exhibited activities against } N \text {. gonorrhoeae, G. vaginalis, and } O \text {. } \\
\text { ureolytica with MIC values }>8.0 \mathrm{mg} / \mathrm{ml}\end{array}$ & Seleteng-Kose et al., 2019 \\
\hline Antibacterial & Organic & Whole plant & Micro-dilution assay & $\begin{array}{l}\text { Exhibited activities with } \mathrm{MIC} \text { value of } 0.1 \mathrm{mg} / \mathrm{ml} \text { against } G \text {. } \\
\text { vaginalis, } N \text {. gonorrhoeae }(0.06 \mathrm{mg} / \mathrm{ml}) \text {, and } \text { O. ureolytica }(7.2 \\
\mathrm{mg} / \mathrm{ml})\end{array}$ & Seleteng-Kose et al., 2019 \\
\hline Antigonorrhea & Aqueous & Whole plant & Micro-dilution assay & $\begin{array}{l}\text { Exhibited activities against } N \text {. gonorrhoeae with MIC value of }>0.3 \\
\mathrm{mg} / \mathrm{ml}\end{array}$ & Mamabolo et al., 2018 \\
\hline Antigonorrhea & Dichloromethane & Whole plant & Micro-dilution assay & $\begin{array}{l}\text { Exhibited activities against } N \text {. gonorrhoeae with MIC value of }>0.3 \\
\mathrm{mg} / \mathrm{ml}\end{array}$ & Mamabolo et al., 2018 \\
\hline Antigonorrhea & n-hexane & Whole plant & Micro-dilution assay & $\begin{array}{l}\text { Exhibited activities against } N \text {. gonorrhoeae with MIC values } \\
\text { ranging from } 0.04 \mathrm{mg} / \mathrm{ml} \text { to } 0.3 \mathrm{mg} / \mathrm{ml}\end{array}$ & Mamabolo et al., 2018 \\
\hline Antigonorrhea & Methanol & Whole plant & Micro-dilution assay & $\begin{array}{l}\text { Exhibited activities against } N \text {. gonorrhoeae with MIC value of }>0.3 \\
\mathrm{mg} / \mathrm{ml}\end{array}$ & Mamabolo et al., 2018 \\
\hline Antimycobacterial & Acetone & Leaves & Agar plate method & $\begin{array}{l}\text { Exhibited activities with MIC value of } 0.1 \mathrm{mg} / \mathrm{ml} \text { against } M \text {. } \\
\text { tuberculosis }\end{array}$ & Meyer et al., 2002 \\
\hline Antimycobacterial & Not applicable & Caespitate & Agar plate method & $\begin{array}{l}\text { Exhibited activities with MIC value of } 0.1 \mathrm{mg} / \mathrm{ml} \text { against } M \text {. } \\
\text { tuberculosis }\end{array}$ & Meyer et al., 2002 \\
\hline
\end{tabular}




\begin{tabular}{|c|c|c|c|c|c|}
\hline Activity tested & Extract & $\begin{array}{l}\text { Plant part/ } \\
\text { compound }\end{array}$ & Model & Effect & Reference \\
\hline Antifungal & Not applicable & Caespitin & Not mentioned & $\begin{array}{l}\text { Exhibited significant antifungal activities against } M \text {. canis, } C \text {. } \\
\text { neoformans, T. mentagrophytes, and T. rubrum (level of activity } \\
\text { not indicated) }\end{array}$ & Dekker et al., 1983 \\
\hline Antifungal & Not applicable & Caespitin & Serial dilution method & $\begin{array}{l}\text { Exhibited activities against tested pathogens with MIC and } \\
\text { minimum fungicidal concentration (MFC) values of } 25.0 \mu \mathrm{g} / \mathrm{ml} \text { and } \\
100.0 \mu \mathrm{g} / \mathrm{ml} \text { against C. albicans, C. tropicalis }(50.0 \mu \mathrm{g} / \mathrm{ml}, 100.0 \\
\mu \mathrm{g} / \mathrm{ml}), \text { A. corymbifera }(100.0 \mu \mathrm{g} / \mathrm{ml},>100.0 \mu \mathrm{g} / \mathrm{ml}), \text { A. fumigatus } \\
(100.0 \mu \mathrm{g} / \mathrm{ml}, 100.0 \mu \mathrm{g} / \mathrm{ml}), S . \text { schenkii }(25.0 \mu \mathrm{g} / \mathrm{ml}, 50.0 \mu \mathrm{g} / \mathrm{ml}), T \text {. } \\
\text { rubrum }(6.0 \mu \mathrm{g} / \mathrm{ml}, 6.0 \mu \mathrm{g} / \mathrm{ml}), \text { T. mentagrophytes }(6.0 \mu \mathrm{g} / \mathrm{ml}, 13.0 \\
\mu \mathrm{g} / \mathrm{ml}) \text {, and } \text { M. canis }(6.0 \mu \mathrm{g} / \mathrm{ml}, 13.0 \mu \mathrm{g} / \mathrm{ml})\end{array}$ & Van der Schyf et al., 1986 \\
\hline Antifungal & Acetone & Aerial parts & Agar dilution method & $\begin{array}{l}\text { Exhibited activities with MIC value of } 0.01 \mathrm{mg} / \mathrm{ml} \text { against } A \text {. niger, } \\
C \text {. sphaerospermum, C. cucumerinum, and } C \text {. cladosporioides, and } \\
\text { MIC value of } 1.0 \mathrm{mg} / \mathrm{ml} \text { against } A \text {. flavus and } P \text {. capsici }\end{array}$ & Mathekga et al., 2000 \\
\hline Antifungal & Acetone & Caespitate & Agar dilution method & $\begin{array}{l}\text { Exhibited activities with MIC value of } 0.5 \mathrm{mg} / \mathrm{ml} \text { against } C \text {. } \\
\text { cucumerinum and } C \text {. sphaerospermum, MIC value of } 1.0 \mathrm{mg} / \mathrm{ml} \\
\text { against } A \text {. flavus, } A \text {. niger, and } P \text {. capsici, and MIC value of } 5.0 \\
\mathrm{mg} / \mathrm{ml} \text { against } C \text {. cladosporioides }\end{array}$ & Mathekga et al., 2000 \\
\hline Antifungal & Aqueous & Whole plant & Micro-dilution assay & $\begin{array}{l}\text { Exhibited activities against } C \text {. albicans } \text { with } \text { MIC value of }>8.0 \\
\mathrm{mg} / \mathrm{ml}\end{array}$ & Seleteng-Kose et al., 2019 \\
\hline Antifungal & Organic & Whole plant & Micro-dilution assay & $\begin{array}{l}\text { Exhibited activities against } C \text {. albicans with MIC value of } 0.02 \\
\mathrm{mg} / \mathrm{ml}\end{array}$ & Seleteng-Kose et al., 2019 \\
\hline Antioxidant & Acetone & Whole plant & $\begin{array}{l}\text { 2,2-dipheny-1- } \\
\text { picrylhydrazyl (DPPH) } \\
\text { free radical scavenging } \\
\text { assay }\end{array}$ & Exhibited activities with $\mathrm{IC}_{50}$ value of $0.06 \mathrm{mg} / \mathrm{ml}$ & Mamabolo et al., 2017 \\
\hline Antioxidant & Aqueous & Whole plant & $\begin{array}{l}\text { DPPH free radical } \\
\text { scavenging assay }\end{array}$ & Exhibited activities with $\mathrm{IC}_{50}$ value of $0.05 \mathrm{mg} / \mathrm{ml}$ & Mamabolo et al., 2017 \\
\hline Antioxidant & Dichloromethane & Whole plant & $\begin{array}{l}\text { DPPH free radical } \\
\text { scavenging assay }\end{array}$ & Exhibited activities with $\mathrm{IC}_{50}$ value of $0.06 \mathrm{mg} / \mathrm{ml}$ & Mamabolo et al., 2017 \\
\hline Antioxidant & n-hexane & Whole plant & $\begin{array}{l}\text { DPPH free radical } \\
\text { scavenging assay }\end{array}$ & Exhibited activities with $\mathrm{IC}_{50}$ value of $0.06 \mathrm{mg} / \mathrm{ml}$ & Mamabolo et al., 2017 \\
\hline Antioxidant & Methanol & Whole plant & $\begin{array}{l}\text { DPPH free radical } \\
\text { scavenging assay }\end{array}$ & Exhibited activities with $\mathrm{IC}_{50}$ value of $0.05 \mathrm{mg} / \mathrm{ml}$ & Mamabolo et al., 2017 \\
\hline Antioxidant & Acetone & Whole plant & $\begin{array}{l}\text { Hydrogen peroxide } \\
\text { scavenging assay }\end{array}$ & Exhibited activities with $\mathrm{IC}_{50}$ value of $0.3 \mathrm{mg} / \mathrm{ml}$ & Mamabolo et al., 2017 \\
\hline Antioxidant & Aqueous & Whole plant & $\begin{array}{l}\text { Hydrogen peroxide } \\
\text { scavenging assay }\end{array}$ & Exhibited activities with $\mathrm{IC}_{50}$ value of $0.08 \mathrm{mg} / \mathrm{ml}$ & Mamabolo et al., 2017 \\
\hline Antioxidant & Dichloromethane & Whole plant & $\begin{array}{l}\text { Hydrogen peroxide } \\
\text { scavenging assay }\end{array}$ & Exhibited activities with $\mathrm{IC}_{50}$ value of $0.4 \mathrm{mg} / \mathrm{ml}$ & Mamabolo et al., 2017 \\
\hline Antioxidant & n-hexane & Whole plant & $\begin{array}{l}\text { Hydrogen peroxide } \\
\text { scavenging assay }\end{array}$ & Exhibited activities with $\mathrm{IC}_{50}$ value of $0.2 \mathrm{mg} / \mathrm{ml}$ & Mamabolo et al., 2017 \\
\hline Antioxidant & Methanol & Whole plant & $\begin{array}{l}\text { Hydrogen peroxide } \\
\text { scavenging assay }\end{array}$ & Exhibited activities with $\mathrm{IC}_{50}$ value of $0.2 \mathrm{mg} / \mathrm{ml}$ & Mamabolo et al., 2017 \\
\hline Antioxidant & Acetone & Whole plant & Reducing power assay & Exhibited activities with $\mathrm{IC}_{50}$ value of $0.3 \mathrm{mg} / \mathrm{ml}$ & Mamabolo et al., 2017 \\
\hline Antioxidant & Aqueous & Whole plant & Reducing power assay & Exhibited activities with $\mathrm{IC}_{50}$ value of $>0.5 \mathrm{mg} / \mathrm{ml}$ & Mamabolo et al., 2017 \\
\hline Antioxidant & Dichloromethane & Whole plant & Reducing power assay & Exhibited activities with $\mathrm{IC}_{50}$ value of $>0.5 \mathrm{mg} / \mathrm{ml}$ & Mamabolo et al., 2017 \\
\hline Antioxidant & n-hexane & Whole plant & Reducing power assay & Exhibited activities with $\mathrm{IC}_{50}$ value of $0.09 \mathrm{mg} / \mathrm{ml}$ & Mamabolo et al., 2017 \\
\hline Antioxidant & Methanol & Whole plant & Reducing power assay & Exhibited activities with $\mathrm{IC}_{50}$ value of $0.4 \mathrm{mg} / \mathrm{ml}$ & Mamabolo et al., 2017 \\
\hline Cytotoxicity & Dichloromethane & Whole plant & $\begin{array}{l}\text { 3-(4,5-dimethylthiazol- } \\
\text { 2-yl)-2,5-diphenyl } \\
\text { tetrazolium bromide } \\
\text { (MTT) calorimetric } \\
\text { assay in H411E rat } \\
\text { hepatoma (liver) cell } \\
\text { lines }\end{array}$ & $\begin{array}{l}\text { Exhibited weak activities with the median lethal concentration } \\
\left(\mathrm{LC}_{50}\right) \text { value of } 82.9 \mu \mathrm{g} / \mathrm{ml} \text { which was higher than } \mathrm{LC}_{50} \text { value of } \\
10.8 \mu \mathrm{g} / \mathrm{ml} \text { exhibited by the control }\end{array}$ & Mamabolo et al., 2018 \\
\hline
\end{tabular}

values for C. albicans, C. tropicalis, A. corymbifera, A. fumigatus, and $S$. schenkii were within the range of 25.0 to $>100.0 \mu \mathrm{g} / \mathrm{ml}$. These results were within the same range as MIC and MFC values exhibited by nystatin, the positive drug which exhibited 2.0 to $>100.0 \mu \mathrm{g} / \mathrm{ml}$ (Van der Schyf et al., 1986). Mathekga (2001) and Mathekga et al. (2000) evaluated the antifungal activities of acetone extracts of aerial parts of $H$. caespititium against M. canis, Aspergillus niger, Aspergillus flavus, Cladosporium sphaerospermum, Cladosporium cladosporioides, M. canis, and Cladosporium cucumerinum using agar dilution method. The extract showed properties against all the tested pathogens with the MIC values within the range of $0.01-1.0 \mathrm{mg} / \mathrm{ml}$ (Mathekga, 2001; 
Mathekga et al., 2000). Mathekga et al. (2000) also evaluated the antifungal activities of the compound caespitate isolated from $H$. caespititium against C. sphaerospermum, Phytophthora capsici, A. niger, C. cucumerinum, A. flavus, and C. cladosporioides using agar dilution method. The compound was active against all tested pathogens with the MIC values within the range of $0.5-5.0 \mu \mathrm{g} /$ $\mathrm{ml}$ (Mathekga et al., 2000). Seleteng-Kose et al. (2019) assessed the antifungal properties of water and organic extracts of whole plant parts of $H$. caespititium against $C$. albicans using the microdilution assay with amphotericin $\mathrm{B}(0.1 \mathrm{mg} / \mathrm{ml})$ as the positive drug. The organic extracts showed moderate properties with the MIC values of $0.02 \mathrm{mg} / \mathrm{ml}$, while the MIC value exhibited by aqueous extract was $>8.0 \mathrm{mg} / \mathrm{ml}$ (Seleteng-Kose et al., 2019).

\section{Antioxidant activities}

Mamabolo et al. (2017) assessed the antioxidant activities of dichloromethane, n-hexane, acetone, methanol, and aqueous extracts of whole plant parts of $H$. caespititium using hydrogen peroxide scavenging, 2,2-diphenyl-1-picrylhydrazyl (DPPH) free radical scavenging and reducing power assays with ascorbic acid and butylated hydroxytoluene (BHT) as positive controls. The extracts exhibited properties with half maximal inhibitory concentration $\left(\mathrm{IC}_{50}\right)$ values within the range of $0.05-0.6$ $\mathrm{mg} / \mathrm{ml}$ which were within the $\left(\mathrm{IC}_{50}\right)$ values of 0.04 to $>0.5 \mathrm{mg} / \mathrm{ml}$ exhibited by the positive drugs (Mamabolo et al., 2017).

\section{Cytotoxicity activities}

Mathekga (2001) evaluated the cytotoxicity activities of the compound caespitate isolated from $H$. caespititium on vervet monkey kidney cells using the 3-(4,5 dimethylthiazol2-yl) 2,5-diphenyl tetrazolium bromide (MTT) technique. The maximum non-toxic concentration of the bioactive compound on the vervet kidney monkey cell cultures was $50 \mathrm{mg} / \mathrm{ml}$ and at this level the cells did not show any morphological alterations or any signs of growth indicating some cytotoxic effects (Mathekga, 2001). Mamabolo et al. (2018) assessed cytotoxicity properties of n-hexane, dichloromethane, methanol, and aqueous extracts of whole plant parts of $H$. caespititium in $\mathrm{H} 411 \mathrm{E}$ rat hepatoma (liver) cell lines using the MTT technique with doxorubicin as the positive control. The extracts exhibited weak activities with the median lethal concentration $\left(\mathrm{LC}_{50}\right)$ values ranging from $82.9-428.8 \mu \mathrm{g} / \mathrm{ml}$ which were much higher than $\mathrm{LC}_{50}$ value of $10.8 \mu \mathrm{g} / \mathrm{ml}$ showed by the positive control (Mamabolo et al., 2018). These results suggest that the plant extract can safely be used without any worries of being toxic to the cells. Seleteng-Kose et al. (2019) assessed cytotoxicity properties of water and organic extracts of whole plant parts of $H$. caespititium using the brine shrimp (Artemia franciscana) lethality assay with potassium dichromate as a positive drug. The extracts appear to be non-toxic as aqueous and organic extracts caused $3.3 \%$ and $40.7 \%$ mortality of $A$. franciscana after 24 hours in comparison to $98 \%$ and $100 \%$ mortality displayed by the positive control, potassium dichromate (Seleteng-Kose et al., 2019). Based on these evaluations done so far, there is a need for more research in order to establish the safety of extracts and isolated (bioactive) compounds from $H$. caespititium.

\section{CONCLUSION}

The diverse medicinal uses of $H$. caespititium and the scientific evidence of its biological activities indicate its potential as the herbal medicine. Its diverse pharmacological activities are directly or indirectly involved associated with a wide range of physiological processes which offers protection against growth of undesirable microbes and free radicals. There is a need for evaluation of the clinical significance of the antioxidant properties, cytotoxicity, and toxicity using in vivo models. Future research should also focus on assessing the classes of phytochemical compounds associated with the species. The biological potency of such phytochemicals needs to be evaluated aimed at exploring their potential.

\section{ACKNOWLEDGMENTS}

The author would like to express my gratitude to the National Research Foundation (NRF), South Africa and Govan Mbeki Research and Development Centre (GMRDC), University of Fort Hare for financial support to conduct this study.

\section{CONFLICT OF INTEREST}

The author declares that he has no conflict of interest.

\section{REFERENCES}

Adebayo SA, Masoko P. Therapeutic uses of plant species for inflammation-related conditions in Limpopo province of South Africa: a mini-review and current perspectives. Int J Pharmacog Phytoth Res, 2017; 1(1):2-8.

Ajao AA, Sibiya NP, Moteetee AN. Sexual prowess from nature: a systematic review of medicinal plants used as aphrodisiacs and sexual dysfunction in sub-Saharan Africa. S Afr J Bot, 2018.

Arnold TH, Prentice CA, Hawker LC, Snyman EE, Tomalin M, Crouch NR, Pottas-Bircher C. Medicinal and magical plants of southern Africa: an annotated checklist. National Botanical Institute, Pretoria, South Africa, 2002.

Chinsembu KC. Diabetes mellitus and nature's pharmacy of putative antidiabetic plants. J Herbal Med, 2018; 15.

Cook FEM. Economic botany data collection standard. Prepared for the International Working Group on Taxonomic Databases for Plant Sciences (TDWG), Kew Royal Botanic Gardens, Kew, London, UK, 1995.

Dekker TG, Fourie TG, Snyckers FO, Van der Schyf CJ. Studies of South African medicinal plants. part 2 caespitin, a new phloroglucinol derivative with antimicrobial properties from Helichrysum caespititium. S Afr J Chem, 1983; 36:114-6.

Erasmus LJC, Potgieter MJ, Semenya SS, Lennox SJ. Phytomedicine versus gonorrhoea: the bapedi experience. Afr J Trad Compl Alt Med, 2012; 9(4):591-8.

Fabian A, Germishuizen G. Wild flowers of northern South Africa. Fernwood Press, Vlaeburg, South Africa, 1997.

Gelfand M, Mavi S, Drummond RR, Ndemera B. The traditional medical practitioners in Zimbabwe: his principles of practice and pharmacopoeia. Mambo Press, Gweru, Zimbabwe, 1995.

Germishuizen G, Meyer NL. Plants of southern Africa: an annotated checklist. Strelitzia 14, National Botanical Institute, Pretoria, South Africa, 2003.

Gruca M, Cámara-Leret R, Macía MJ, Balslev $\mathrm{H}$ New categories for traditional medicine in the Economic Botany Data Collection Standard. J Ethnopharmacol, 2014; 155(2): 1388-92.

Hilliard OM. Compositae in natal. University of Natal Press, Pietermaritzburg, South Africa, 1977.

Hilliard OM. Gnaphaliinae. In: Leistner OA (ed.). Flora of Southern Africa: Asteraceae. National Botanical Institute, Pretoria, pp. $1-325,1983$. 
Hutchings A, Van Staden J. Plants used for stress related ailments in traditional Zulu, Xhosa and Sotho medicine. Part 1. Plants used for headaches. J Ethnopharmacol, 1994; 43:89-124.

Hyde MA, Wursten BT, Ballings P, Coates Palgrave M. Helichrysum caespititium (DC.) Harv. Flora of Zimbabwe: Species Information: Helichrysum caespititium. 2019 [Online]. Available via https:// www.zimbabweflora.co.zw/speciesdata/species.php?species_id=159510 (Accessed 12 February 2019).

Jacot Guillarmod A. Flora of Lesotho (Basutoland). Cramer, Lehre, Germany, 1971.

Long C. Swaziland's flora: siSwati names and uses. Mbambane, Swaziland: Swaziland National Trust Commission. 2019 [Online]. Available via http://www .sntc.org.sz/index.asp (Accessed 4 February 2019).

Macía MJ, Armesilla PJ, Cámara-Leret R, Paniagua-Zambrana N, Villalba S, Balslev H, Pardo-de-Santayana M. Palm uses in northwestern South America: a quantitative review. Bot Rev, 2011; 77(4):462-570.

Maliehe EB. Medicinal plants and herbs of Lesotho. Mafeteng Development Project, Maseru, Leostho, 1997.

Mamabolo MP, Muganza FM, Olivier MT. Free radical scavenging and antibacterial activities of Helichrysum caespititium (DC) Harv. extracts. Biol Med, 2017; 9:6.

Mamabolo MP, Muganza FM, Olivier MT, Olaokun OO, Nemutavhanani LD. Evaluation of antigonorrhea activity and cytotoxicity of Helichrysum caespititium (DC) Harv. whole plant extracts. Biol Med, 2018; 10:1

Mammino L, Kabanda MM. Model structures for the study of acylated phloroglucinols and computational study of the caespitate molecule. J Mol Str Theochem, 2007; 805:39-52.

Mammino L, Kabanda MM. The geometric isomers of caespitate: a computational study in vacuo and in solution. Int J Biol Biomedical Eng, 2012; 6(1):114-33.

Maroyi A. Dicoma anomala Sond.: a review of its botany, ethnomedicine, phytochemistry and pharmacology. Asian J Pharm Clin Res, 2018; 11(6):70-7.

Mathekga ADM. Antimicrobial activity of Helichrysum species and the isolation of a new phloroglucinol from Helichrysum caespititium. $\mathrm{PhD}$ Thesis, University of Pretoria, Pretoria, South Africa, 2001.

Mathekga ADM, Meyer JJM, Horn MM, Drewes SE. An acylated phloroglucinol with antimicrobial properties from Helichrysum caespititium. Phytochem, 2000; 53:93-6.

Meyer JJM, Lall N, Mathekga ADM. In vitro inhibition of drug-resistant and drug-sensitive strains of Mycobacterium tuberculosis by Helichrysum caespititium. S Afr J Bot, 2002; 68:90-3.

Moffett R. Sesotho plant and animal names and plants used by the Basotho. African Sun Media, Bloemfontein, South Africa, 2010.

Molebatsi LY. An assessment of the useful plant diversity in homegardens and communal land of Tlhakgameng, North-West. MSc dissertation, North-West University, Potchefstroom, South Africa, 2011

Moteetee A, Moffett RO, Seleteng-Kose L. A review of the ethnobotany of the Basotho of Lesotho and the Free State province of South Africa (South Sotho). S Afr J Bot, 2018.

Moteetee A, Seleteng-Kose L. Medicinal plants used in Lesotho for treatment of reproductive and post reproductive problems. J Ethnopharmacol, 2016; 194:827-49.

Moteetee A, Van Wyk B-E. The medical ethnobotany of Lesotho: a review. Bothalia, 2011; 41(1):209-28.

Mugomeri E, Chatanga P, Chakane N. Medicinal herbs used by HIV-positive people in Lesotho. Afr J Trad Compl Alt Med, 2016a; 13(4):123-31.

Mugomeri E, Chatanga P, Raditladi T, Makara M, Tarirai C. Ethnobotanical study and conservation status of local medicinal plants: towards a repository and monograph of herbal medicines in Lesotho. Afr J Trad Compl Alt Med, 2016b; 13(1):143-56.

Pooley E. A field guide to wild flowers of KwaZulu-Natal and the eastern regions. Natal Flora Publication Trust, Durban, South Africa, 1998.
Pooley E. Mountain flowers: a field guide to the flora of the Drakensberg and Lesotho. The Flora Publications Trust, Durban, South Africa, 2003.

Reddy D. The phytochemistry and antimicrobial activity of selected indigenous Helichrysum species. MSc dissertation, University of the Witwatersrand, Johannesburg, South Africa, 2007.

Schmitz MO. Wild flowers of Lesotho. ESSA, Roma, Lesotho, 1982.

Seleteng-Kose L, Moteetee A, Van Vuuren S. Ethnobotanical survey of medicinal plants used in the Maseru district of Lesotho. J Ethnopharmacol, 2015; 170:184-200.

Seleteng-Kose L, Moteetee A, Van Vuuren S. Medicinal plants used for the treatment of sexually transmitted infections in the Maseru district, Lesotho: antimicrobial validation, phytochemical and cytotoxicity studies. S Afr J Bot, 2019

Semenya SS, Maroyi A. Medicinal plants used by the Bapedi traditional healers to treat diarrhoea in the Limpopo province, South Africa. J Ethnopharmacol, 2012; 144:395-401.

Semenya SS, Maroyi A. Plants used by Bapedi traditional healers to treat asthma and related symptoms in Limpopo province, South Africa. Evid Based Compl Alt Med, 2018a; 2018:Article ID 2183705.

Semenya SS, Maroyi A. Data on medicinal plants used to treat respiratory infections and related symptoms in South Africa. Data Brief, $2018 b ; 21: 419-23$.

Semenya SS, Maroyi A. Therapeutic plants used by traditional health practitioners to treat pneumonia in the Limpopo province, South Africa. Latin Amer Caribbean Bull Med Aromatic Pl, 2018c; 17(6):583603

Semenya SS, Maroyi A. Source, harvesting, conservation status, threats and management of indigenous plant used for respiratory infections and related symptoms in the Limpopo province, South Africa. Biodiversitas, 2019a; 20(3):790-811.

Semenya SS, Maroyi A. Source of plants, used by Bapedi traditional healers for respiratory infections and related symptoms in the Limpopo province, South Africa. J Biol Sci, 2019b; 19(2):101-21.

Semenya SS, Potgieter MJ, Erasmus LJC. Ethnobotanical survey of medicinal plants used by Bapedi healers to treat diabetes mellitus in the Limpopo province, South Africa. J Ethnopharmacol, 2012; 141:440-5.

Semenya SS, Potgieter MJ, Erasmus LJC. Indigenous plant species used by Bapedi healers to treat sexually transmitted infections: their distribution, harvesting, conservation and threats. S Afr J Bot, 2013; 87:66-75.

Semenya SS, Wadesango N. Ethnobotanical survey of plants used by Bapedi traditional healers to treat hypertension in the Polokwane Munucipality, Limpopo province, South Africa. Indilinga Afr J Indig Knowl Syst, 2018; 17(1):109-29.

Staub PO, Geck MS, Weckerle CS, Casu L, Leonti M. Classifying diseases and remedies in ethnomedicine and ethnopharmacology. J Ethnopharmacol, 2015; 174:514-9.

Van Der Schyf CJ, Dekker TG, Fourie TG, Snyckers FO Synthesis and antimicrobial activity of a series of caespitin derivatives. Antimicrob Agents Chemother, 1986; 30(3):375-81.

Watt JM, Brandwijk MG. Suto (Basuto) medicines. Bantu Stud, 1927; 3:73-100.

Watt JM, Breyer-Brandwijk MG. The medicinal and poisonous plants of southern and eastern Africa. E \& S Livingstone, Edinburgh, London, 1962.

How to cite this article:

Maroyi A. Helichrysum caespititium (DC.) Harv.: Review of its medicinal uses, phytochemistry and biological activities. J Appl Pharm Sci, 2019; 9(06):111-118. 